\title{
The Basin of Mexico aquifer system: Regional groundwater table dynamics and database development
}

\author{
J. J. Carrera-Hernández ${ }^{1, *}$, S. J. Gaskin \\ McGill University, Department of Civil Engineering and Applied Mechanics, 817 Sherbrooke \\ Street West, Montreal QC, $\mathrm{H}_{3} \mathrm{~A}$ 2K6, Canada
}

\begin{abstract}
The aquifer system of the Basin of Mexico is the main source of water supply to the Mexico City Metropolitan Zone. The management of the Basin's water resources requires improved undertanding of regional groundwater flow patterns, for which large amounts of data are required. The current study analyses the regional dynamics of the potentiometric groundwater level in the entire Basin using data collected in a new regional database called the Basin of Mexico Hydrogeological Database (BMHDB). In order to foster the development of a regional view of the Basin's aquifer system the BMHDB has been developed collecting data on climatological, borehole and runoff variables from different sources. The structure and development of the BMHDB are briefly explained and then the database is used to analyze the consequences of groundwater extraction on the aquifer's confinment conditions using lithology data. The regional analysis shows that the largest drawdown rates are located north of Mexico City, in Ecatepec, a region that has not yet received attention in hydrogeological studies, due to two lines of wells that were drilled as a temporarily solution to Mexico City's water supply problem. This work also shows how the aquifer has changed from a confined to an unconfined condition in some areas, a factor that is responsible for the large subsidence rates $(40 \mathrm{~cm} /$ year $)$ in some regions.
\end{abstract}

Key words: GIS, Drawdown, Database, Mexico City, Basin of Mexico, Regional studies

\footnotetext{
* Corresponding author.

Email addresses: jaime . carrera@mail .mcgill.ca (J. J. Carrera-Hernández), susan.gaskin@mcgill.ca (S. J. Gaskin).

1 Current address: International Institute for Applied Systems Analysis (IIASA), Schloss-
} 
2 Groundwater represents the main water source in many regions, including the Basin 3 of Mexico, on which the Mexico City Metropolitan Zone (MCMZ) and its nearly 20 million inhabitants are located. The Basin's aquifer system provides nearly $70 \%$ of the Basin's total water supply, while most of the remainder is provided by water taken from other regions such as the Cutzamala and Lerma basins. Despite the importance that the aquifer system plays in the Basin's water supply, to date no regional studies have been developed. A regional approach is needed in the Basin in order to start managing the Basin's aquifer system. As a first step to foster a regional approach, a new database called the Basin of Mexico Hydrogeological Database (BMHDB) has been developed by gathering data which were previously available in different locations and formats. In addition, the BMHDB has been developed with Open Source Software in order to make data accessible to people who can not acquire proprietary software due to its cost. Using this approach, the BMHDB has already been used to analyze daily climatological data (rainfall and both minimum and maximum temperature) in the Basin by Carrera-Hernández and Gaskin (2007).

7. The important role that the aquifer system plays as the main water source in the Basin 18 has caused a regional drawdown of the groundwater potentiometric level, which in 19 turn has caused land subsidence due to the compressible nature of the lacustrine 20 sediments that overlie most of the regional aquifer system. To this date, most stud21 ies have focused on the area on which the MCMZ is located, ignoring other areas 22 which exhibit drawdown rates of near $3 \mathrm{~m}$ /year and which may have similar or larger 23 subsidence rates than those of Chalco and Texcoco, the focus of previous studies. 24 In order to change the existing piece-wise aquifer approach, this work analyzes the 25 spatial evolution of the regional groundwater potentiometric level in the Basin from 261975 to 2000 in six time steps using data on the spatial distribution of extraction 27 rates and lithology data which are part of the BMHDB. This approach shows how 28 the aquitard's thickness changes within the Basin and how in some areas the aquifer is no longer confined.

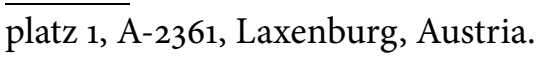




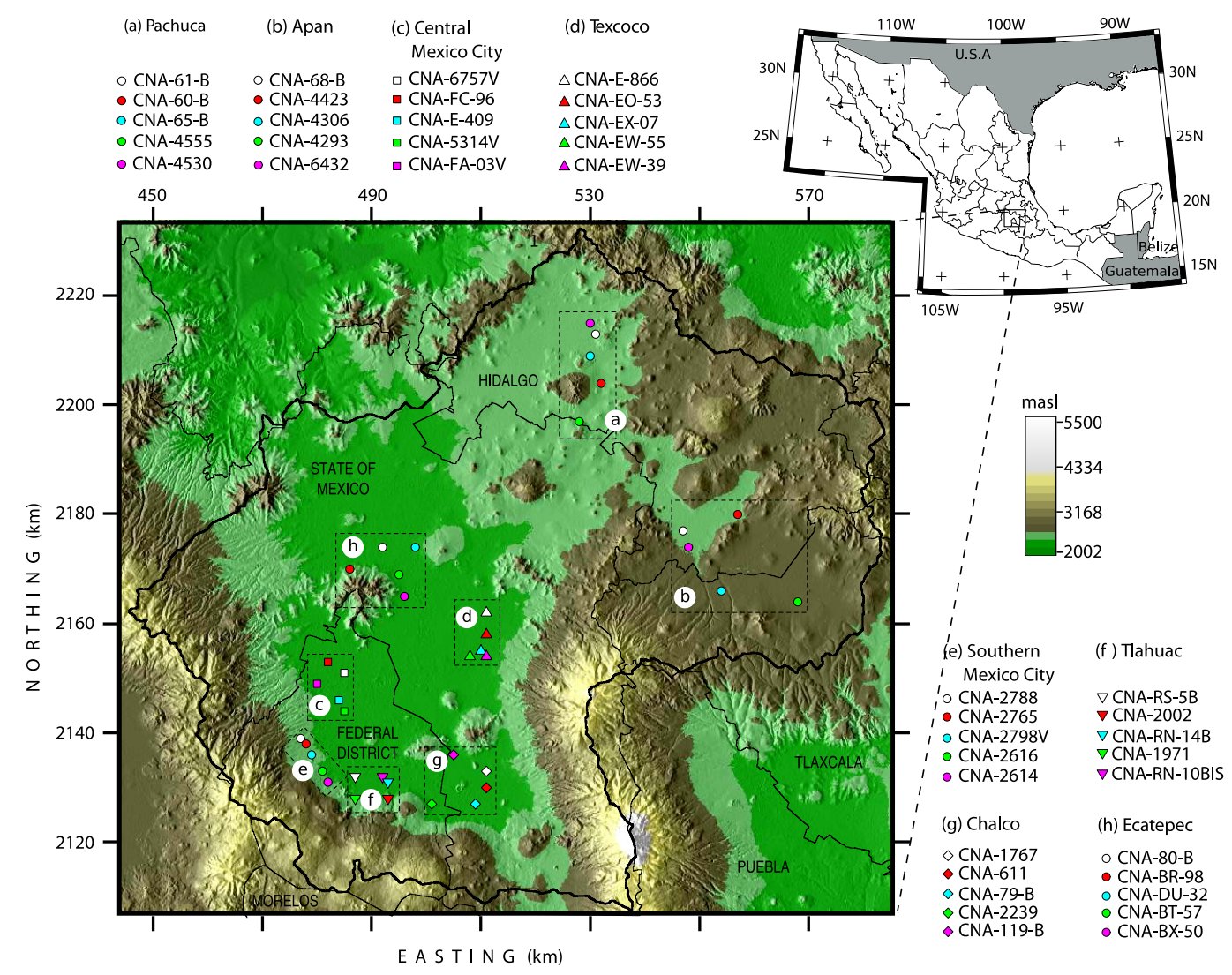

Fig. 1. Location, topography and selected monitoring wells in the Basin of Mexico. The Basin is shown in UTM-14 coordinates. The monitoring wells are used for the long term analysis of drawdown in six different areas.

\section{The Basin of Mexico}

2 The Basin of Mexico (referred to as the Basin in the remainder of the paper) with 3 an approximate area of $9,600 \mathrm{~km}^{2}$ encloses one of the largest cities in the world: 4 Mexico City and its Metropolitan zone (MCMZ). The Basin is located in the central 5 part of Mexico between the meridians $99^{\circ} 30^{\prime} \mathrm{W}, 98^{\circ} 10^{\prime} \mathrm{W}$ and the parallels $19^{\circ} 10^{\prime} \mathrm{N}$, $620^{\circ} 10^{\prime} \mathrm{N}$; it has a mean altitude of 2240 meters above sea level (masl) and is enclosed 7 by mountains as high as 5500 masl (Fig. 1).

8 The Basin's aquifer system is the most important part of the water supply system

9 for its inhabitants and its exploitation started in 1847 , when the first well was drilled 10 (Ortega and Farvolden, 1989). By 1899 a total of 1070 wells were used to extract water 11 from the aquifers (Marroquin-Rivera, 1914), a number that increased throughout 12 the last century. Water extraction from the aquifer in 1950 was $13.7 \mathrm{~m}^{3} / \mathrm{s}$ while water 13 imported from the Lerma basin accounted for $6.0 \mathrm{~m}^{3} / \mathrm{s}$ (Mazari and Alberro, 1990). 
By 1990 a total of 3537 officially registered wells were located in the MCMZ (NRC, 1995). Exploitation of the aquifer system in the Basin has caused land subsidence problems; from the beginning of the XXth century until 1938 the land subsidence rate was $4.6 \mathrm{~cm} /$ year which increased in the following decade to $16 \mathrm{~cm} /$ year (NRC,

1995). By this time, authorities realized that water pumping was the main cause of land subsidence in the city and closed the wells located in the center of the City. With this policy, land subsidence rate went down to $7.5 \mathrm{~cm} /$ year and by the end of the $80 \mathrm{~s}$ its mean value was $4.5 \mathrm{~cm} /$ year (Mazari and Alberro, 1990). Net subsidence over the last century has lowered the central part of the urban area more than $7.5 \mathrm{~m}$ (NRC, 1995: Figueroa-Vega, 1984) while in Azcapotzalco its value is up to $30 \mathrm{~m}$ (Birkle et al., 1998).

Compounding this problem, the Basin comprises five different political entities: the Federal District, State of Mexico, Hidalgo, Puebla and Tlaxcala (Fig. 1); accordingly, different governmental agencies are in charge of water supply, the most important being the Comisión Nacional del Agua (CNA) and the Dirección General de Construcción y Operación Hidráulica (DGCOH). The CNA has under its charge the Gerencia Regional de Aguas del Valle de México (GRAVAMEX) which in conjunction with the DGCOH operates the water supply infrastructure for the MCMZ. However, water management at the basin level is not fulfilled as these agencies operate on their own, making it difficult to share information between them.

\subsection{Hydrogeological setting}

The Basin of Mexico has a large aquifer system as the intense volcanism in this area hinders the existence of isolated aquifers (Mooser and Molina, 1993). The surface geology of the Basin (Fig. 2) shows the different geological units in the area, which exhibit different hydraulic properties. The main hydrogeological unit is the Quaternary alluvial unit (Qal) on which the extraction wells are located and which according to Herrera et al. (1989) is exploited to a maximum depth of 300 meters and which reaches a maximum thickness of nearly $800 \mathrm{~m}$ in the southern area of the Basin. This main unit is partially covered by Quaternary lacustrine deposits (Qla) which in prepumping times confined part of the aquifer system. The Qla unit is thicker in its central areas, reaching a maximum of $300 \mathrm{~m}$ in the Chalco sub-basin, located at the $\mathrm{SE}$ region of the Basin, while its minimum value $(3 \mathrm{O} \mathrm{m})$ is found towards the north 
and on the plain's limits (Vázquez-Sánchez and Jaimes-Palomera, 1989). Within this

unit a sand unit is located and generally referred to as capas duras which has large hydraulic conductivity values and a thickness of nearly 3 meters. The Qal unit is interlayered with the Quaternary basalts $(\mathrm{Qb})$ of the Sierra Chichinautzin and other volcanoes in the southern region of the Basin. The Quaternary basalts have large permeability values due to its large number of fractures thus providing an adequate route for aquifer recharge. The high mountains that limit the Basin to the east are formed by andesitic basalts (Qn) which lie above the Tarango formation (T) also found at the bottom of the Sierra de las Cruces and are comprised of tuff, pummice and lahar (Mooser and Molina, 1093). These units are limited by the Pliocene lacustrine deposits (Pl) which consist of highly consolidated clays (Mooser and Molina, 1993).

The need for accessible and up-to-date data at the Basin level is shown from recent studies undertaken within or near the Basin of Mexico as they have considered only subareas of the Basin or relied on short term records. Studies that have used limited rainfall data to compute the mean rainfall value of the Basin include Birkle et al. (1998) who developed a "long-term" water balance for the study area using rainfall data for the 1980-1985 period. Downs et al. (2000) relied on previous studies such as the one by Ramirez-Sama (1990) who used data from 1930-1970. Studies focusing on particular sub-regions of the Basin include Huizar-Álvarez et al. (2003) who studied the Pachuca-Zumpango sub-basin and Huizar-Álvarez et al. (2001) who analyzed the Tecocomulco region located in the north-eastern part of the Basin with an area of $585 \mathrm{~km}^{2}$.

\section{The Basin of Mexico Hydrogeological Database}

Data required for any type of surface or groundwater study in the Basin is currently spread throughout different agencies in charge of water supply and within these agencies data are found in different reports. Furthermore, the existing databases are limited to particular data such as climatological data or run-off data. In order to improve water management in the Basin and to foster an Integrated Water Management approach in the study area, the Basin of Mexico Hydrogeological Database (BMHDB) has been developed using both a Relational Database Management System (RDBMS) and a Geographic Information System (GIS). The BMHDB comprises 


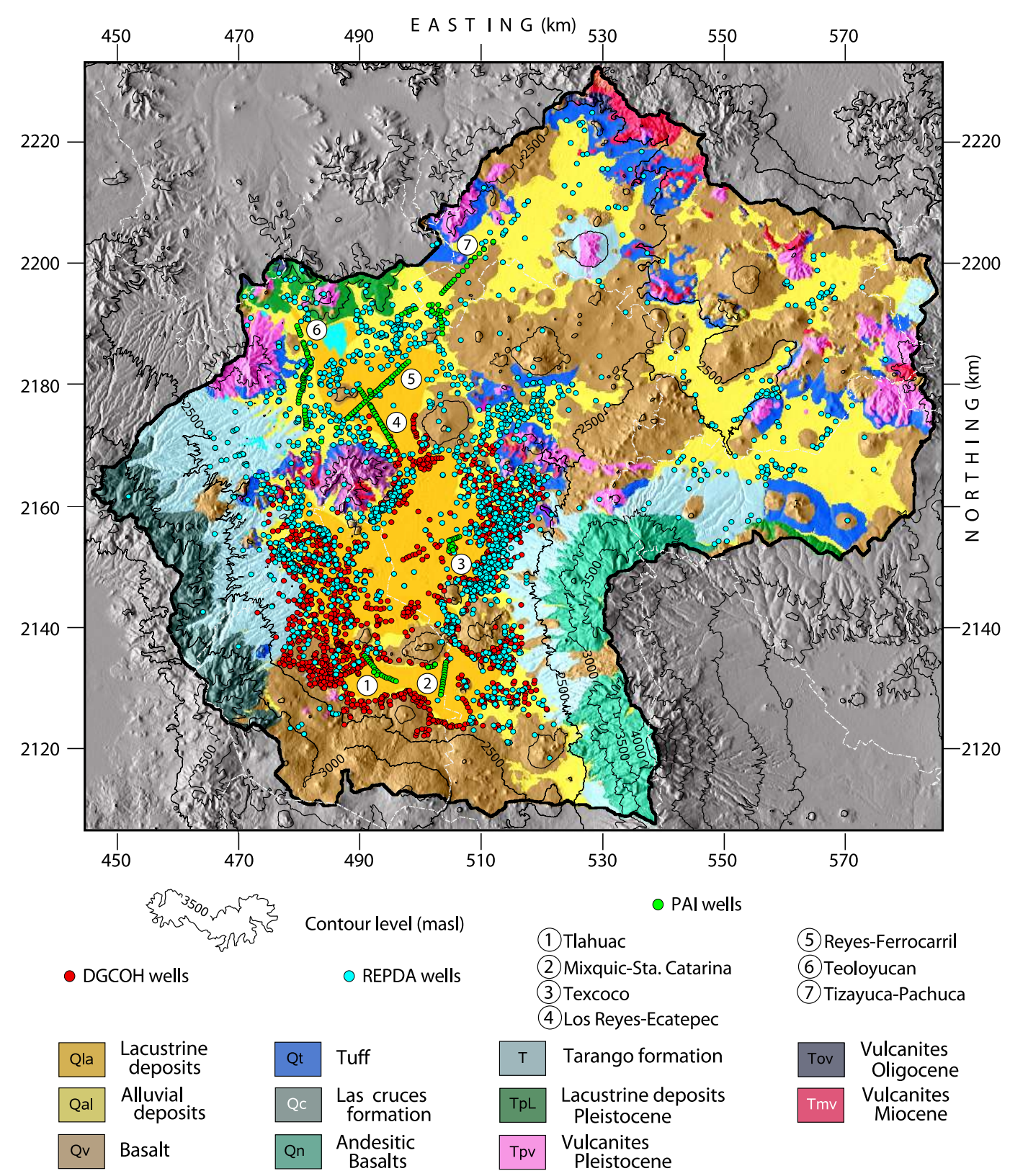

Fig. 2. Surface Geology for the Basin of Mexico and extraction wells, which are color-coded according to the agency from which data were compiled. Coordinates are in $\mathrm{km}$, UTM zone 14. Geology adapted from Mooser et al. (1996), shaded relief derived from Shuttle Radar Topography Mission data.

1 monitoring wells from both CNA and DGCOH, and extraction wells registered at 2 the Registro Público de Derechos de Agua (REPDA), DGCOH and other wells such 3 as the Pozos de Acción Inmediata (PAI) as shown in Fig. 2. In addition, lithology 4 records, pumping tests and chemical data are available for some extraction bore5 holes. Climatological data such as rainfall depths, temperature and pan evaporation 6 are available. In order to build this database, the authors gathered this information 
which is currently distributed in the water supply agencies (DGCOH, CNA), in previous studies realized in sub-areas of the Basin and existing databases. The information gathered to date was obtained in different formats, such as spreadsheet files, vector files, hard-copy maps (e.g. soils and land-use), hand written tables and reports. This information was processed and georefenced in order to provide readily accessible data for hydrogeological modeling.

\subsection{Database structure}

The BMHDB contains both spatial and point data. Spatial data such as soil units, surface geology and topography are stored in the GRASS GIS as raster maps, while point data such as those recorded at wells and both climatological and gauging stations are stored in relational tables. The point data stored in the BMHDB comprises 18 different tables which are grouped in three sub-databases: climatological records, well and run-off data. In order to ease the maintenance of well data, the well identifiers (id) are preceded by a prefix (e.g. CNA, DGOCH) which reflects the agency from where data were gathered and which also avoids duplication. The BMHDB is a relational database, which means that different tables are related to each other by a unique identifier which in the case of well data, is the well's id. The well database comprises nine different tables: One is the main table which has general data such as the well's id, coordinates, name, elevation, total depth and diameter; the information stored by this main table can be expanded depending on the general data available. The remaining eight well-related data tables, which are related to the main table by the well's id are lithology, metals, pumping test data, chemical data, groundwater table elevation, extraction rates and screen depths; unfortunately these data tables are not available for all wells but the structure of the database allows for easy updating and addition of more data as they become available. The database is accessed through Standard Query Language (SQL) commands and statistical analysis can be undertaken through the $\mathrm{R}$ statistical package $\mathrm{R}$ Development Core Team, 2005) and its libraries such as GSTAT (Pebesma, 2004) for spatial interpolation. The database was designed in a way that facilitates adding new records as they become available and can be easily implemented in other regions, where depending on the available data the tables can have more or less information. 


\section{Evolution of the potentiometric level in the Basin}

The BMHDB was used to analyze the evolution of the potentiometric level in the Basin in order to analyze the effect that groundwater extraction has caused on aquifer conditions. It should be stressed that this analysis would have been limited both geographically and temporally if the BMHDB had not been developed, as the DGCOH started the development of a monitoring piezometric network in the southern part of the Basin in 1984 (DGCOH and Lesser, 1991) which complements the long-term data from the CNA's monitoring wells, as some of the CNA wells have data from 1969. In this way, the monitoring network is enriched by the density of the DGOCH wells in the southern area of the Basin and the long term data from the CNA wells, which are distributed throughout the Basin.

The drawdown rate varies across the Basin, as illustrated in Fig. 3 which shows the potentiometric groundwater level for 1969-2002 recorded at 40 monitoring wells located in eight different regions in the Basin (Fig. 1). In general, all wells show that the potentiometric ground water level in the Basin is decreasing, except in Apan located in the eastern part of the Basin (Fig. 1). The level recorded in the four wells located in this area is almost constant, except for well CNA-6432 (Fig. 3(b)), found in the city of Apan. The largest drawdown rates in the Basin are found in the Ecatepec area, just north of Federal District (Fig. 1) as the level recorded in Ecatepec at well CNA-80-B (Fig. 3(h)) shows a total drawdown of nearly $70 \mathrm{~m}$ for the period 19752002. It is interesting to note the evolution of the potentiometric level in southern Mexico City (fig. 3(e)). A continuous drawdown occurs from 1969 to 1992, then the potentiometric level starts to rise in three of the wells located in this area, which may have been caused by a reduction in the extraction rates. A similar behavior is observed in Tláhuac (Fig $3(\mathrm{f})$ ) in those wells located at a similar elevation to those of the previous region at approximately 2300 masl (Fig. 1).

The spatial analysis of the evolution of the potentiometric elevation between 19752000 was undertaken for six time steps: 1975, 1980, 1985, 1990, 1994 and 2000 as illustrated in Fig. 4, which was developed by using GSTAT (Pebesma, 2004) within $\mathrm{R}$ ( $\mathrm{R}$ Development Core Team, 2005) and written as different GRASS raster files by using R's library spgrass (Bivand, 2000). The contour lines shown on Fig. 4 are limited to the areal extension of the Alluvial sediments (Qal, Fig. 2), in which the white color line represents the potentiometric level of 2200 masl. In 1975 the 2200 con- 


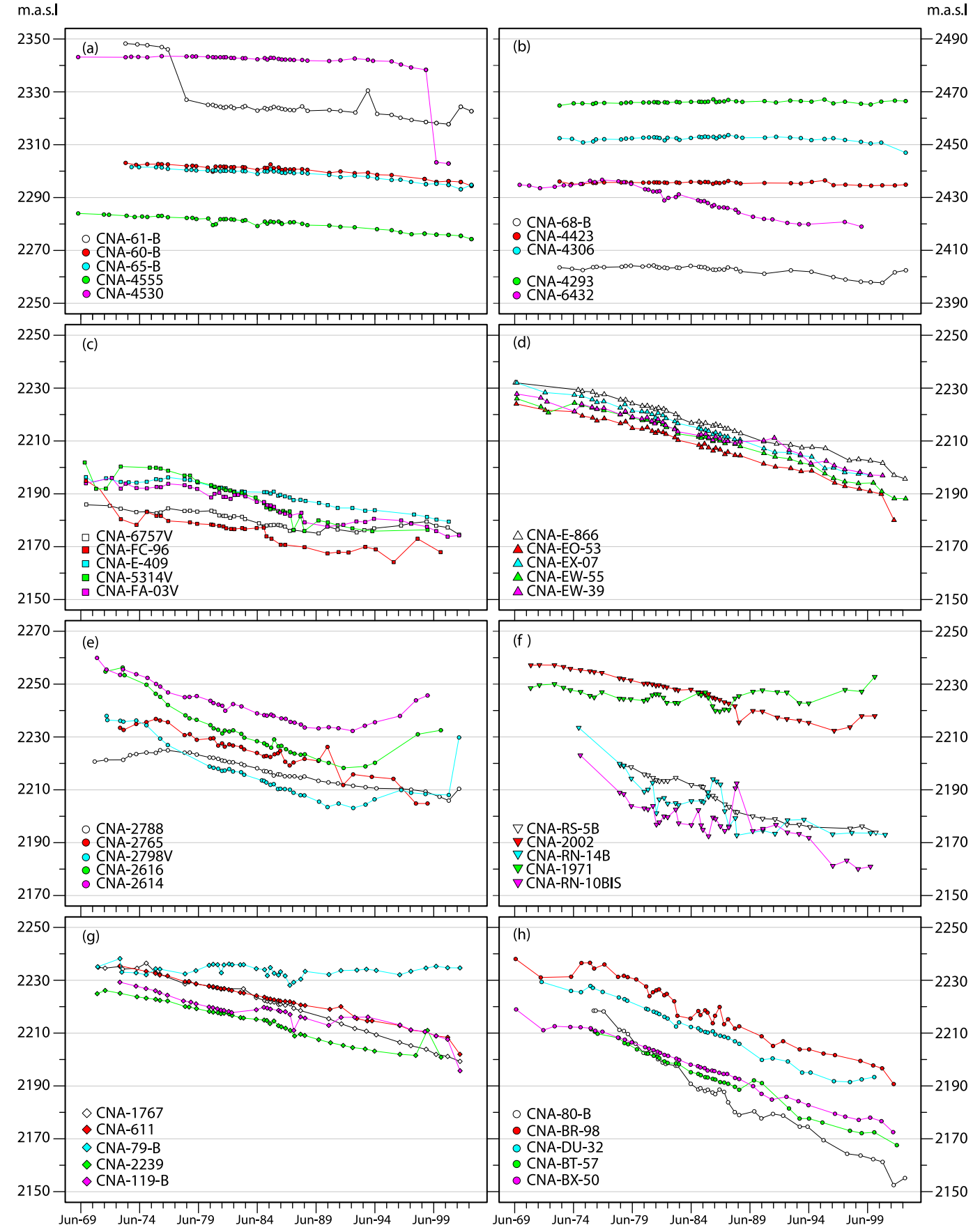

Fig. 3. Evolution of groundwater table elevation for 40 wells distributed in different areas in the Basin as shown in Fig. 1: (a) Pachuca, (b) Apan, (c) Central Mexico City, (d) Texcoco, (e) Southern Mexico City, (f) Tláhuac, (g) Chalco and (h) Ecatepec

1 tour line enclosed a small area in the northern area of the Federal District, near the

2 Sierra de Guadalupe while for year 2000 the area enclosed by this contour increases 3 to nearly the entire region in the central part of the Basin. For this last year, Fig. 4(f)

4 shows that the areas with a potentiometric level below 2180 masl have increased on 
both Ecatepec and Teoloyucan, while the contour line of 2200 masl has appeared on Chalco.

The main consequence of the large extraction rates in the Basin is land subsidence, which is not a new problem, as it was discovered by Roberto Gayol in 1925 (Figueroa-Vega, 1984). According to Ortega-Guerrero et al. (1999) the Chalco Basin is the area with the largest subsidence rate, with approximately $0.4 \mathrm{~m} /$ year. However this rate is also noticed in other areas of the Basin such as in the Texcoco area as shown by Strozzi et al. (2003) who used Synthetic Aperture Radar data to determine land subsidence in the southern part of the Basin. Unfortunately this study only analyzed land subsidence south of the Sierra de Guadalupe and did not include the areas in which a large depression of the potentiometric level is observed: Teoloyuca, Xaltocan (Reyes-Ferrocarril) and Ecatepec (Fig. 4). These depression areas are found in those regions where the Plan de Acción Inmediata (PAI) wells (fig. 2) were drilled in the 70 as a temporary solution to Mexico City's water supply problem. Although a decline in the potentiometric level in this area can be observed in the early 7os, an abrupt change is noticeable in 1974 (Fig. 3(h)), when these wells started to operate. The effect of the PAI wells in the Teoloyucan-Chiconutla area are easily noticed by 1980 (Fig. 4(b)) when the 2200 potentiometric contour appears in Teoloyucan and the potentiometric levels lower in the Xaltocan-Ecatepec areas. In general the drawdown rate in the Basin is approximately $1 \mathrm{~m} /$ year. The largest drawdown rates in the Basin are observed in well CNA-8o-B which is located in the Los Reyes-Ecatepec well system and very close to the Los Reyes-Ferrocarriles system, with an approximate drawdown rate of $2.5 \mathrm{~m} /$ year; while the drawdown rates observed on the other wells in this region are nearly $1.8 \mathrm{~m} /$ year. These rates can be explained by the large pumping rates in this area, as in 2003, the Teoloyucan system provided $1.6 \mathrm{~m}^{3} / \mathrm{s}$, Los Reyes-Ferrocarril $1.69 \mathrm{~m}^{3} / \mathrm{s}$ and Los reyes-Ecatepec $1.27 \mathrm{~m}^{3} / \mathrm{s}$ (CNA, 2004). This contrasts with the extraction rates of the PAI system in the southern area of the Basin: $0.69 \mathrm{~m}^{3} / \mathrm{s}$ in Tláhuac, and $0.60 \mathrm{~m}^{3} / \mathrm{s}$ both in Mixquic and Texcoco (CNA, 2004). Following this line of thought, the next section will focus on the analysis of the potentiometric level and the location of pumping rates using the data in the BMHDB on extraction rates for 1993-1998 for some DGCOH wells, allowed extractions from REPDA wells and extraction rates for 2001-2002 from the PAI wells. 

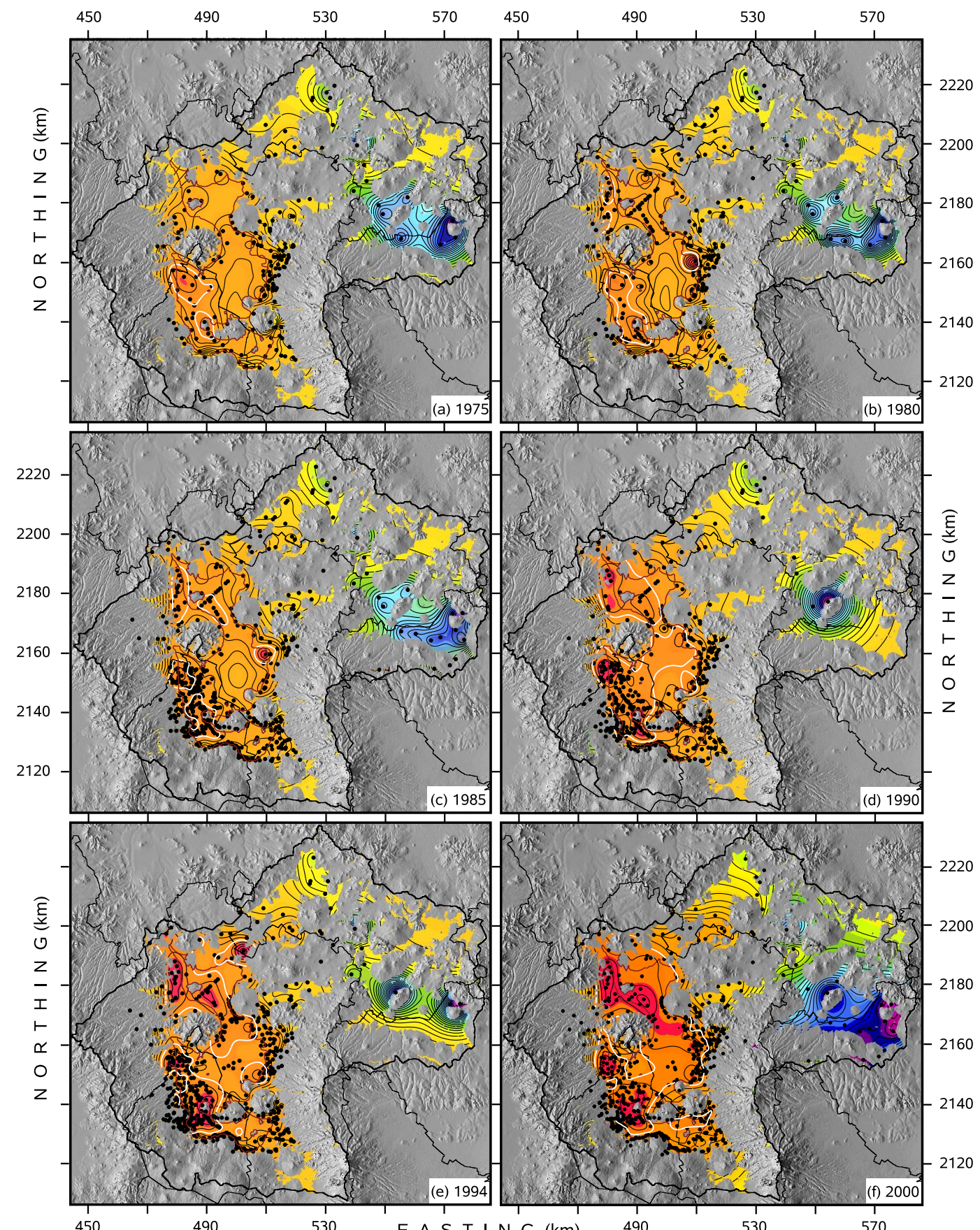
The importance of a regional database in the Basin of Mexico is illustrated in Fig. 5 which shows the spatial distribution of pumping rates in the Basin, which are color coded according to the agency from which data were gathered, also showing the groundwater table elevation for 2000 at intervals of 5 meters. Before any analysis is made using this figure, it should be pointed out that the pumping rates shown for the REPDA wells represent abstraction permits and not actual extraction rates as these data are not available.

The spatial distribution of pumping rates (Fig. 5) shows that large amounts of groundwater are extracted from the aquifer in the southern region of the Basin, where the MCMZ is located and that the REPDA is incomplete, as it is supposed to include all water extraction permits, either ground or surface water (i.e. it should contain data on the DGCOH wells); from Fig. 2 and Fig. 5 it can be concluded that this not the case. None of the wells located at the base of Sierra Chichinautzin are part of the REPDA, nor are many located in the Federal District and near Cerro Barrientos as shown by the numerous wells indicated by the red dots in Fig. 2. In addition, the extraction rates of the DGCOH are in general larger than the allowed extraction volumes from most of the REPDA wells (Fig. 5). The PAI wells also have large extraction rates, and these wells have caused an impressive drawdown area north of Mexico City in Teoloyucan and Los Reyes due to two PAI well lines located in this area (fig. 2): Los Reyes-Ecatepec and Los Reyes-Ferrocarril. Although Fig. 5 does not show all the wells of the Tizayuca-Pachuca well line but only the southern most ones, a large drawdown is expected to develop in that region, as was the case in 1994, when the potentiometric level was as low as 2180 masl (Fig. 4(e)) and which probably increased due to a change in pumping rates in this area.

\subsection{Analysis of confinment conditions}

The Basin's aquifer system was confined by the lacustrine deposits before pumping started, as piezometric levels were approximately $2.7 \mathrm{~m}$ above the land surface in the mid XIXth century in the Central part of Mexico City and 3-7 m above land surface in Texcoco in 1954 (Durazo and Farvolden, 1983). In this section, the spatial distribution of the groundwater table elevation for 1971, 1980, 1990 and 2000 (Fig. 6) is used 


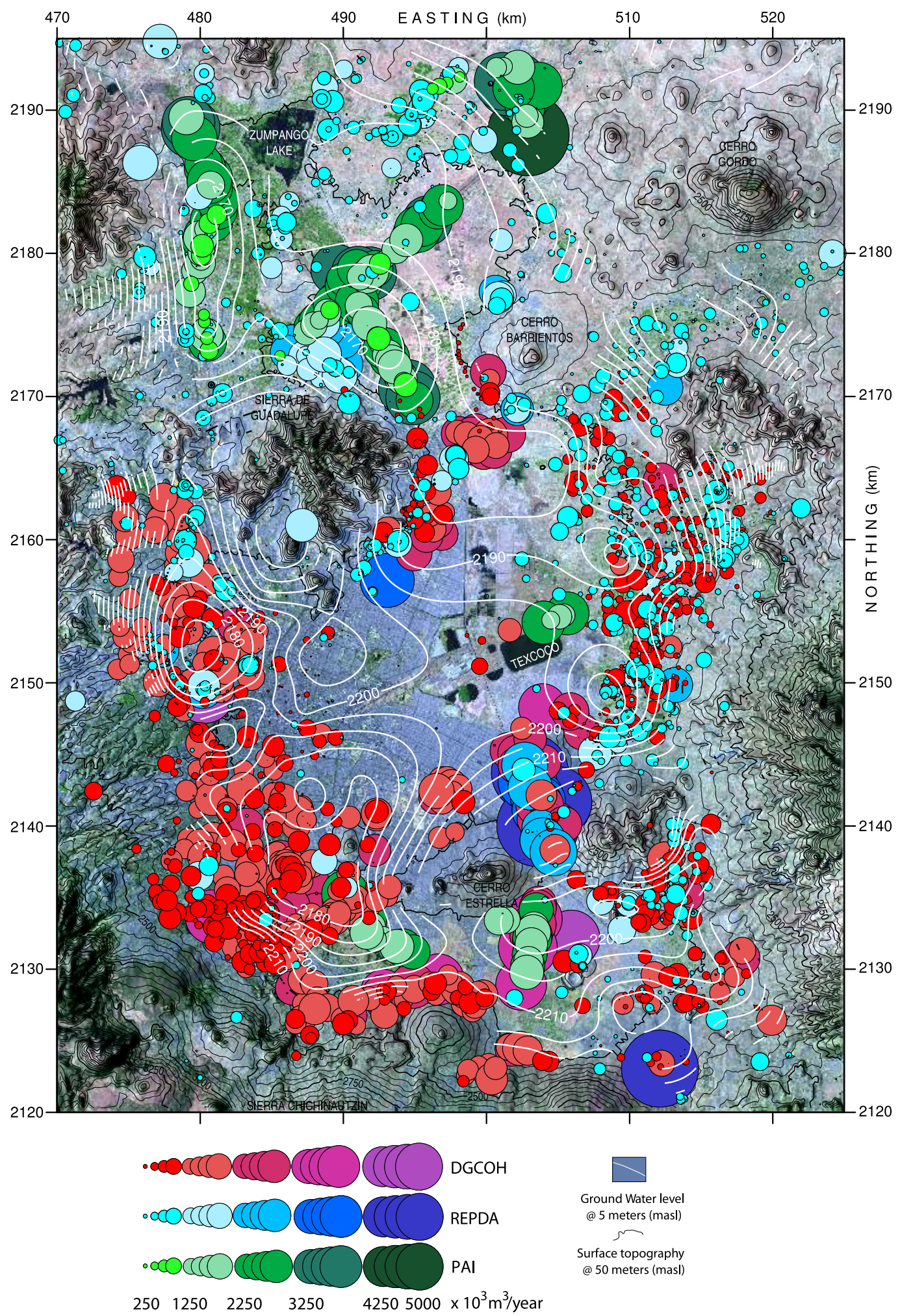

Fig. 5. Spatial distribution of pumping rates in the Basin of Mexico overlying a LANDSAT false color composite showing urban areas in light purple. Red colored circles represent welldata obtained from the DGCOH, blue colored from the REPDA and green colored from PAI wells. Groundwater level contours are for 200o. Coordinates are in km, UTM reference system, zone 14 
Table 1

Lithology material and associated ids and symbols

\begin{tabular}{llrlll} 
Material & ID & Symbol & Material & ID & Symbol \\
\hline andesite & 1 & lapilli & 37 \\
basalt & 3 & 49 \\
basalt with tezontle & 5 & sand & 51 \\
breccia & 8 & sand with clay & 51 \\
clay & 9 & sand with gravel & 55 \\
clay with sand & 15 & silt \\
conglomerate & 26 & tarango & 75 \\
gravel & 25 & tuff & 81
\end{tabular}

1 together with the lithology data stored in the BMHDB in order to verify the change 2 that the aquifer system has had from confined to unconfined conditions. In order to do so, seven different geological cross sections located in different parts of the Basin are used, as illustrated in Fig. 6. In addition, to the wells that have lithology information, Fig. 6 also shows the monitoring wells used to illustrate the evolution of the potentiometric groundwater level from 1969-2002 in the previous section (Fig. 3). A total of 90 different materials ids were used to describe the lithology data available in the Basin, but only 16 are used in the present work, as described in Table 1 which shows both the ids and symbols used for each lithology material. The colors used in these symbols were chosen in order to match those of the surface geology map (Fig. 2) as fine sediments are shown in orange color in order to match the Qla deposits while coarse sediments are represented in yellow color to match the Qal deposits.

3 The seven geological cross sections (Fig. 7) were located in different areas in order 14 to analyze the aquifer's confining condition from 1971-2000. The first of these cross 15 sections is located in Chalco where according to Ortega-Guerrero et al. (1992) the la16 custrine deposits reach their maximum thickness of nearly $300 \mathrm{~m}$. As shown in this 17 cross section (Fig. 7(a)) artesian conditions were present in 1971 towards the south18 ern and northern limits of the lacustrine deposits in Chalco, which changed near the 19 Sierra Sta. Catarina by 1980 and at both limits of the deposits by 1990 . The second cross section (b-b', not shown), located south of the Sierra de Guadalupe shows that the potentiometric level has remained constant at this section's northern limit, while a drawdown of nearly 50 meters is observed at its southern limit. This is explained 


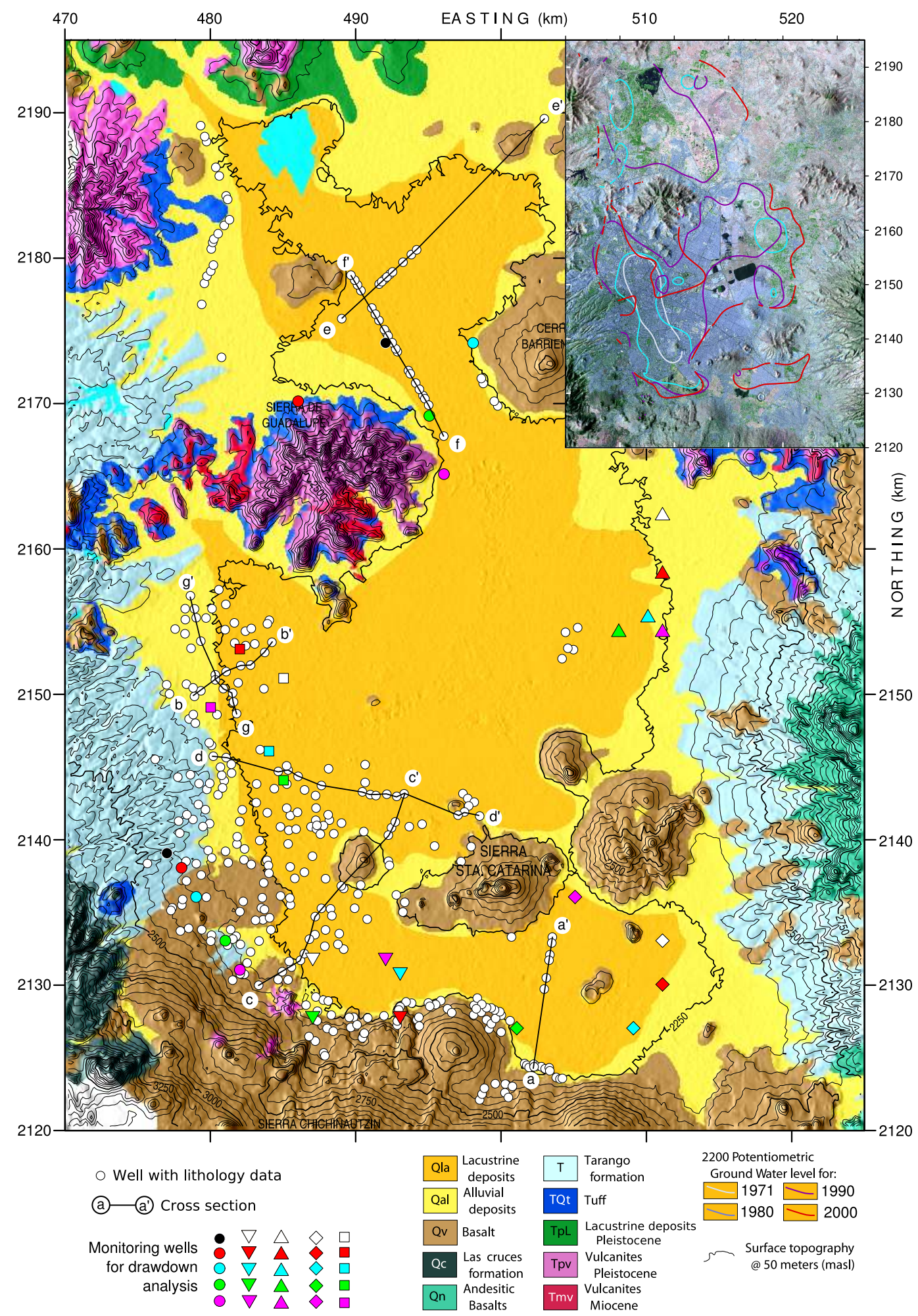

Fig. 6. Wells with lithology data in the Basin of Mexico. The inset figure shows the evolution of the 2200 masl potentiometric level from 1971-2000 for the same area on a LANDSAT false color composite on which urban areas are shown in light purple. 
1 by the location of the wells in this area (Fig. 5) as they are located towards the limit 2 of the lacustrine deposits; it is important to notice that the available data show that 3 the aquifer was unconfined even in 1971 in this region.

4 The third cross section (c-c', not shown), which starts at the base of the Sierra Chichin5 autzin shows how the potentiometric level is lower towards the Cerro de la Estrella 6 both at its southern and northern contacts with the granular aquifer, which is also ex7 plained by the large extraction rates in this area (Fig. 5). The geological cross section 8 d-d' extends from the base of the Sierra de las Cruces to the north of Sierra de Santa Catarina and shows clearly how the thickness of the lacustrine deposits increases 10 towards the Valley's center; it also shows that north of Cerro de la Estrella basalt 11 rocks are found below the lacustrine deposits. This cross section illustrates how the aquifer changes from an unconfined to a confined condition towards the center of the plain and that the potentiometric level increases towards its eastern end. Moving northwards, to where the largest drawdown values are found (Fig. 3), section e-e' 5 (Fig. $7(\mathrm{e})$ ) extends across the Reyes-Ferrocarril well line and it is interesting to note 16 the drastic change in the potentiometric level from 1971 to 1980 , which was caused 17 by the fact that these PAI wells started to operate in 1974. As shown in this cross 18 section, the potentiometric level has maintained a constant decrease which accord19 ing to Fig. 5 is caused by the PAI wells, as the remainder wells in this area have low 20 extraction rates. The same pattern is observed in section $\mathrm{f}-\mathrm{f}^{\prime}$ (not shown) on which 21 the lacustrine sediments are intercalated with coarse deposits and tuff towards the section's northern limit. From these two sections, it appears that the aquifer is still confined in this region. 

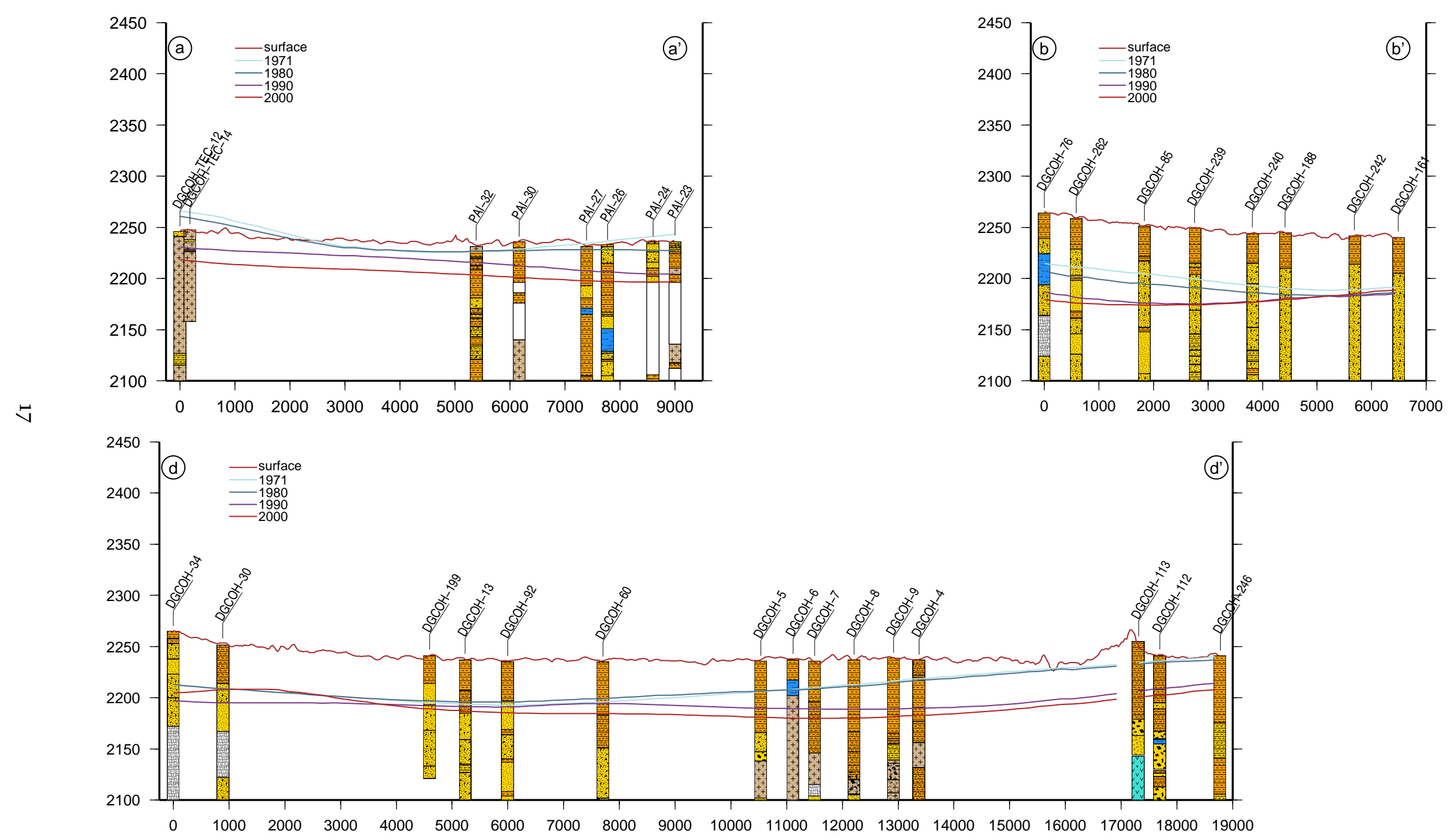

Fig. 7. Geological cross sections in the Basin of Mexico showing the groundwater level for 1971, 1980, 1990 and 2000. The lithology is explained in Table 1 


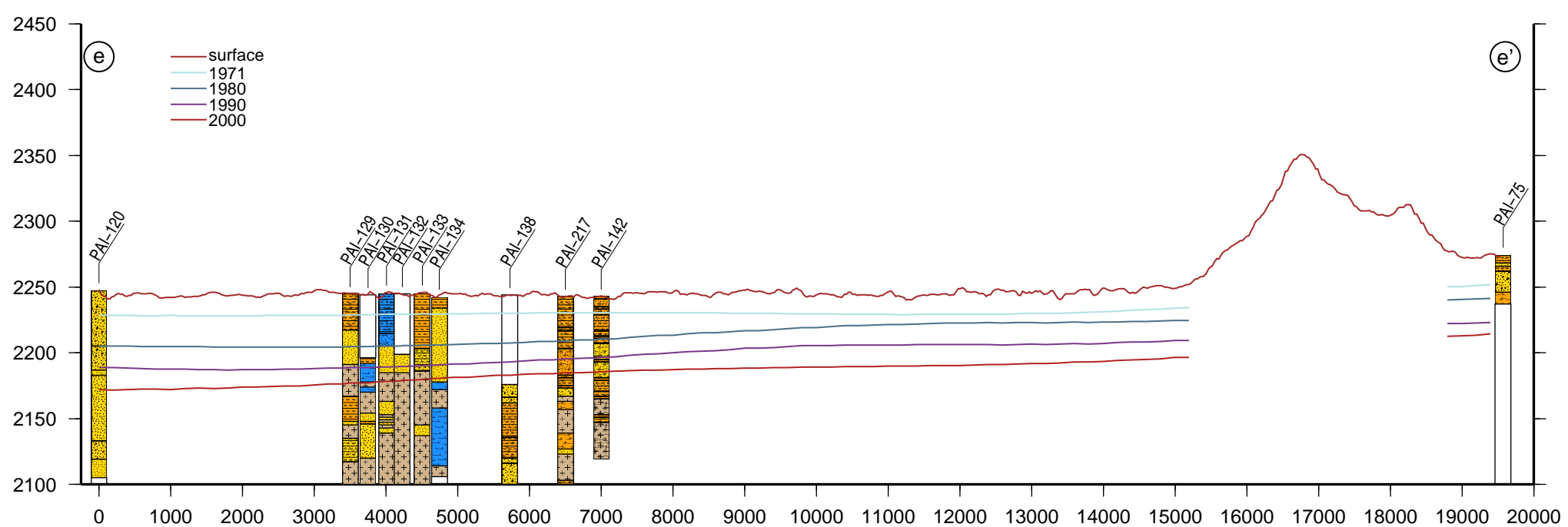




\section{Discussion}

The Basin of Mexico encloses not only Mexico City and its Metropolitan Zone (MCMZ), but other urban areas as well. Evidently, the size and importance of the MCMZ has triggered the development of studies in the area covered by it, but this has led to a misleading approach, as the aquifer from which water is extracted in the MCMZ is part of a regional aquifer system, a fact that has not been taken into consideration. The first step towards a regional aquifer view, is the development of a regional hydrogeological database, which motivated the development of the Basin of Mexico Hydrogeological Database (BMHDB). The BMHDB provides readily accessible data, as its data can be used "as-is" to develop groundwater flow models through the use of the r.gmtg module (Carrera-Hernández and Gaskin, 2006) in the GRASS GIS which directly uses GRASS' data files in MODFLOW, avoiding the process of importing and exporting data from a GIS to a Graphic User Interface (GUI) of a groundwater flow modelling software. It should be mentioned that data stored in the BMHDB comprises officially registered wells; however, non registered wells exist throughout the Basin. This adds another uncertainty factor to be considered when groundwater flow modeling is undertaken. Some information such as the wells' coordinates was verified with existing maps when available or by locating them in a map and checking if their location corresponded to that stored in the database.

The geological cross sections used in this work show that artesian conditions were only found in Chalco in the early 1970s (Fig. $7\left(\mathrm{a}-\mathrm{a}^{\prime}\right)$ ), a condition that is not present anymore. The Basin's valley was a groundwater discharge zone (Durazo and Farvolden, 1982); accordingly, the aquifer was confined by the lacustrine deposits, a situation that is currently present in two areas: in the Chalco region in which these deposits reach a maximum thickness of $300 \mathrm{~m}$ and north of Cerro de la Estrella. In certain parts of the Basin such as Central Mexico city and Ecatepec an abrupt decrease of the potentiometric level is found from 1971 to 1980 , the latter being the area in which this change is more acute and caused by the PAI line wells, which started to extract water in 1974 as a "temporary" solution to Mexico City's water supply problem, but which to this date, continue to operate.

The spatial distribution of the potentiometric groundwater level in the Basin shows that more studies are needed in the northern areas of the Basin and not only on the region where the MCMZ is located or in the Chalco area as has been previously done: 
Rivera and Ledoux (1991) used a finite difference method to study land subsidence caused by aquifer pumping in the central part of the Basin; Huizar-Álvarez (1993) developed a finite difference model of groundwater flow for the Chalco-Amecameca area, located in the southeastern part of the Basin. The DGCOH (1994) used another numerical model for an area enclosing part of the Federal District and the State of Mexico. This same government agency (DGCOH, 2001) used another model in order to refine a previous numerical model (DGCOH, 1999) which was used for the Federal District area. The only study north of the sierra de Guadalupe is the one by Huizar-Álvarez et al. (2003) who developed a finite difference model to simulate groundwater flow in the Pachuca-Zumpango sub-basin; none of these studies have considered a regional aquifer system.

The drawdown rate in the Basin is in general around $1 \mathrm{~m} /$ year, but some areas which have not yet been incorporated in previous studies have drawdown rates as large as $2.5 \mathrm{~m} /$ year. In addition, the use of constant head boundaries in previous studies may lead to wrong results as the potentiometric level in the Basin is in constant evolution (Fig. 4 and Fig. 6) and new studies should consider an aquifer system instead of an isolated set of aquifers as previously done; a task that is facilitated by the use of the BMHDB shown in this work.

Future studies in the Basin of Mexico need to consider the presence of a regional aquifer system; in addition an Integrated Water Management Approach is also needed, in order to consider the effect that urban growth has had and will have on aquifer recharge in this area. Although the main recharge areas of the aquifer system are the mountains that surround the Basin, precipitation can also recharge the aquifer by infiltrating through the Qal deposits (Fig. 2), a phenomenon that can not longer occur once the urban area covers the areas in which this happens. This is an issue that needs to be considered in any water management plan in the Basin.

\section{Conclusions}

The Basin of Mexico encloses Mexico City and its Metropolitan Zone (MCMZ), one of the largest cities in the world which extends over two different political units. This has led to the development of hydrogeological studies which have focused on the southern part of the Basin, where the MCMZ is located. The approach taken so 
far has considered the existence of an isolated set of aquifers instead of a regional aquifer and the use of erroneous boundary conditions, as the aquifer's head is in constant evolution. In order to overcome this problem, the Basin of Mexico Hydrogeological Database (BMHDB) has been developed in order to foster a regional hydrogeological approach in the study area and this is the first effort in trying to assemble a comprehensive database for hydrogeological studies in this area. The development of the BMHDB made it possible to highlight that the PAI well lines are causing large subsidence rates in the Basin.

The drawdown rate in the Basin is in general $1 \mathrm{~m} /$ year; however in Apan, in the eastern zone of the Basin, the drawdown rate is almost negligible except for one well located in the city of Apan. This drawdown rate contrasts with the nearly $3 \mathrm{~m} /$ year rate recorded in Ecatepec. By considering a regional system, this work shows that the largest drawdown rates are actually north of the MCMZ, where two well lines, the Reyes-Ecatepec and Reyes-Ferrocarriles started to extract groundwater in 1974 as a temporary water supply source and which to this date, continue to operate. The large extraction rates in this area have had secondary effects such as land subsidence, with rates which might be equal to those of Chalco and Texcoco; unfortunately all hydrogeological studies have focused on the southern region of the Basin. In addition this work has shown that although the aquifer is still confined in some parts, it is not the case towards the limits of the lacustrine deposits. In the early 70 artesian conditions were even present in Chalco in the southeastern part of the Basin, a condition that is not present any more. The approach taken so far, in which an isolated set of aquifers has been considered needs to be changed to a regional approach, in which an aquifer system in the Basin has to be considered.

\section{References}

Birkle, P., Torres-Rodriguez, V., and González-Partida, E. (1998). The water balance for the Basin of the Valley of Mexico and implications for future water consumption. Hydrogeology Journal, 6:500-517.

Bivand, R. S. (2000). Using the R statistical data analysis language on GRASS 5.0 GIS database files. Computers \& Geosciences, 26:1043-1052.

Carrera-Hernández, J. J. and Gaskin, S. J. (2006). The Groundwater Modeling Tool for GRASS (GMTG): Open Source Groundwater Flow Modeling. Computers \& 
Geosciences, 32:339-351.

Carrera-Hernández, J. J. and Gaskin, S. J. (2007). Spatio temporal analysis of daily precipitation and temperature in the Basin of Mexico. Journal of Hydrology. DOI: 10.1016/j.jhydrol.2006.12.021.

CNA (2004). Compendio del agua de la región xiii: Aguas del valle de méxico y sistema cutzamala 2004. http://www.cna.gob.mx/eCNA/Espaniol/Regionales/Gravamex/Publicaciones/compendio.htm.

DGCOH (1994). Diágnostico del estado presente de las aguas subterráneas de la ciudad de méxico y determinación de sus condiciones futuras (diagnosis of the present state of groundwater in mexico city and its future condition). Technical report, Instituto de Geofísica, UNAM.

DGCOH (1999). Estudio para actualizar la base de datos de la modelación del acuífero y simulación mediante modelos matemáticos aplicando diferentes políticas de explotación en el distrito federal. Technical report, DITAPSA Consultores, S.A. de C.V.

DGCOH (2001). Evaluación y análisis de perspectivas para el abastecimiento de agua al distrito federal (evaluation and analysis of different water supplies for the federal district). Technical report, Instituto Mexicano del Petróleo, Universidad Nacional Autónoma de México, Battelle Memorial Institute and Universidad Autónoma Metropolitana.

DGCOH and Lesser (1991). Recarga artificial de agua residual tratada al acuífero del valle de méxico (artificial aquifer recharge with wastewater in the basin of mexico). Ing. Hidr. en México, pages 65-70.

Downs, T. T., Mazari-Hiriart, M., Dominguez-Mora, R., and Suffet, I. H. (2000). Sustainability of least cost policies for meeting Mexico City's future water demand. Wat. Resour. Res., 36(8):2321-2339.

Durazo, J. and Farvolden, R. (1983). The groundwater regime of the valley of mexico from historic evidence and field observations. J. of Hydrology, 112:171-190.

Figueroa-Vega, G. (1984). Case story no. 9.8. méxico, d. f., méxico. In UNESCO, editor, Guidebook to studies of land subsidence due to groundwater withdrawal.

Herrera, I., Martí nez, R., and Hernández, G. (1989). Contribución para la administración científica del agua subterránea de la Cuenca de México. Geof. Internacional, 28-2:297-334.

Huizar-Álvarez, R. (1993). Simulacion matemática del sistema acuífero de chalcoamecameca, méxico (mathematical modelling of the chalco-amecameca aquifer system). Geofísica Internacional, 32(1):57-79. 
1 Huizar-Álvarez, R., Campos-Enriquez, O., Miltre-Salazar, L. M., Alatriste-Vilchis, D., Méndez-Garcia, T., and Juárez-Sánchez, F. (2001). Evaluación hidrogeológica de la subcuenca de Tecocomulco, Estados de Hidalgo, Puebla y Tlaxcala, México. Rev. Mexicana de Ciencias Geológicas, 18(1):55-73.

Huizar-Álvarez, R., Hernández, G., Carrillo-Martinez, M., Carrillo-Rivera, J. J., Hergt, T., and Angeles, G. (2003). Geologic structure and groundwater flow in the Pachuca-Zumpango sub-basin, central Mexico. Environmental Geology, 43(4):385-399.

Marroquin-Rivera, J. (1914). Memoria de las obras de aprovisionamiento de agua potable a la ciudad de méxico (memory of the water supply works for Mexico City).

Mazari, M. and Alberro, J. (1990). Hundimiento de la ciudad de méxico (the sinking of mexico city). In Problemas de la Cuenca de México (Problems in the Basin of Mexico), pages 83-114. El Colegio de México.

Mooser, F. and Molina, C. (1993). Nuevo modelo hidrogeológico para la Cuenca de Mexico. Boletin del centro de investigacion sismica Fundacion Barros Sierra.

Mooser, R., Montiel, A., and Zúñiga, A. (1996). Nuevo mapa geológico de las cuencas de México, Toluca y Puebla. Estratigrafía tectónica regional y aspectos geotérmicos (new gelogical map for the Basins of Mexico, Toluca and Puebla). Comisión Federal de Electricidad.

NRC (1995). Mexico City's Water Supply: Improving the Outlook for sustainability. National Academy of Sciences.

Ortega, A. and Farvolden, R. N. (1989). Computer analysis of regional groundwater flow and boundary conditions in the basin of mexico. J. of Hydrology, 110:271-294.

Ortega-Guerrero, A., Cherry, J. A., and Rudolph, D. L. (1993). Large-scale aquitard consolidation near Mexico City. Ground Water, 31(5):708-718.

Ortega-Guerrero, A., Rudolph, D. L., and Cherry, J. A. (1999). Analysis of long term land subsidence near mexico city: Field investigations and predictive modeling. Water Resources Research, 35:3317-3341.

Pebesma, E. J. (2004). Multivariable geostatistics in S: the gstat package. Computers \& Geosciences, 30:683-691.

R Development Core Team (2005). R: A language and environment for statistical computing. R Foundation for Statistical Computing, Vienna, Austria. ISBN 3900051-07-0.

Ramirez-Sama, C. (1990). El agua en la Cuenca de México. In Problemas de la cuenca del Valle de México, pages 61-8o. El Colegio de México.

Rivera, A. and Ledoux, E. (1991). Nonlinear modeling of groundwater flow and total 
$1 \quad$ subsidence of the mexico city aquifer aquitard system. In Proceedings of the fourth

$2 \quad$ international symposium on land subsidence, may 1991, IAHS Publ. no. 200.

3 Strozzi, T., Wegmüller, U., Werner, C. L., Wiesman, A., and Spreckels, V. (2003). JERS

$4 \quad$ SAR interferometry for land subsidence monitoring. IEEE transactions on geo-

$5 \quad$ science and remote sensing, 41:1702-1708.

6 Vázquez-Sánchez, E. and Jaimes-Palomera, R. (1989). Geología de la cuenca de 7 México. Geofísica Internacional, 28(2):133-19o. 